\title{
Introduction: The Production of Loss
}

\author{
Anna Bohlin, Heidi Grönstrand and Tiina Kinnunen
}

A sense of loss is a driving force in most nationalist movements. In the nineteenth century, nationalist thought regularly activated imaginings of a lost origin, or of the loss of traditions, culture, language, national virtues and characteristics, territory, a Golden Age. The imagined Viking era as a lost common origin, determining national virtues in Scandinavian nationalisms, or the language struggles characterizing Finnish and Estonian nationalisms are only a few examples. The spread of nationalism in our own time is equally frequently fuelled - and explained - by loss, although in reference to other kinds of losses, such as the loss of control or work opportunities. When writing this introduction, the loss of lives due to the corona pandemic increases nationalism across the world. Loss in nationalist discourse is ubiquitous and difficult to overlook; yet the notion of loss has hardly been targeted as an object of inquiry from a historical perspective in the growing field of Nationalism Studies. The Production of Loss provides the opportunity to address the genealogy of loss in nationalist discourses.

Increasingly studies of nationalist mass movements emphasise feelings as an important part of the very definition of nationalism, or at the very least as a pivotal aspect of transforming nationalism from an elite project into a mass movement. ${ }^{1}$ Still, few have examined in detail how emotions were established, shaped, changed, and challenged, nor has the question of how emotions travelled across borders in nineteenth-century nationalisms been properly addressed. One exception is the newly issued anthology Emotions and Everyday Nationalism in Modern European History, which combines the study of emotions with a bottom-up analysis of national identifications. In contrast to the influential concept of "banal nationalism" coined by Michael Billig, Emotions and Everyday Nationalism puts emphasis on the agency of ordinary people and the concrete reproduction of nationhood in their daily

1 For a recent discussion on different conceptions of nationalism, see e.g. Joep Leerssen, National Thought in Europe: A Cultural History (Amsterdam: Amsterdam University Press, 2006), 14-17; Anthony D. Smith, The Nation Made Real: Art and National Identity in Western Europe, 1600-1850 (Oxford: Oxford University Press, 2013), 5-9. On the transition from elite project to mass movement, see also Miroslav Hroch, "From National Movement to the Fullyformed Nation: The Nation-building Process in Europe", in Mapping the Nation, ed. Gopal Balakrishnan (New York and London: Verso, 1996), 78-97. 
lives - nationalism is approached as embodiment, encounters between bodies and objects. ${ }^{2}$ However, neither Billig nor Emotions and Everyday Nationalism focus on loss. And loss is equally absent in research on literary genres, such as the romance and the Gothic novel, engendering emotions in nation-building processes. ${ }^{3}$ Depressing emotions such as grief and nostalgia, normally associated with passivity, became a powerful means of creating affective agency in nineteenth-century nationalist discourse; emotions of deprivation were invoked in order to instigate an emotional turn with mobilizing force. The role of the sense of loss in the transformation of nationalism into a mass movement has yet to be scrutinised.

Research on the development of nationalism in the nineteenth century following Benedict Anderson's, Franco Moretti's and Ernest Gellner's seminal works invites us to think of expanding movements: the enlargement of structures of power, markets, communities, imaginary geographies. Benedict Anderson's concept "imagined communities" understands the spread of nationalism through print media as a sense of belonging with those beyond our reach, an identification with those with whom we do not come in contact. ${ }^{4}$ In a similar vein, Franco Moretti argues that the novel was the symbolic

2 Andreas Stynen, Maarten van Ginderachter, and Xosé M. Núnez Seixas, "Introduction: Emotions and everyday nationalism in modern European history", in Emotions and Everyday Nationalism in Modern European History, eds. Andreas Stynen, Maarten van Ginderachter and Xosé M. Núnez Seixas (London \& New York: Routledge, 2020). See also Reetta Eiranen, Lähisuhteet ja nationalismi: Aate, tunteet ja sukupuoli Tengströmin perheessä 180o-luvun puolivälissä (Tampere: Tampereen yliopiston väitöskirjat 79, 2019). Michael Billig's concept banal nationalism highlights nationhood as a process by which nation states are reproduced in daily, often unnoticed activities. Instead of the history of great men, such questions as how nation is called into existence in everyday language use and how ordinary people express their feelings to "their" nation, become important. Michael Billig, Banal Nationalism (London: Sage, 1995); see also Marco Antonsich and Michael Skey, "Introduction: The Persistence of Banal Nationalism", in Everyday Nationhood: Theorising Culture, Identity and Belonging after Banal Nationalism, eds. Michael Skey and Marco Antonsich (London: Palgrave Macmillan, 2017), 4-6.

3 See e.g. Linda Kaljundi, Eneken Laanes, and Ilona Pikkanen, eds., Novels, Histories, Novel Nations: Historical Fiction and Cultural Memory in Finland and Estonia (Helsinki: The Finnish Literature Society, 2015); P.M. Mehtonen and Matti Savolainen, eds., Gothic Topographies: Language, Nation Building and "Race" (Ashgate: Farnham, 2013); Amelia Sanz, Francesca Scott, and Susan van Dijk, eds., Women Telling Nations: Women Writers in History 1 (Amsterdam \& New York: Rodopi, 2014); Anna Bohlin, "The Novel Reconsidered: Emotions and Anti-Realism in Mid-19th-Century Scandinavian Literature", Nations and Nationalism (published in early view 2021), https://doi.org/10.111//nana.12698. The forerunner in this respect is Doris Sommer, Foundational Fictions: The National Romances of Latin America (Los Angeles \& Oxford: University of California Press, 1991).

4 Benedict Anderson, Imagined Communities: Reflections on the Origin and Spread of Nationalism, revised edition (London: Verso, 2006). 
form of the nation state precisely because the novel was able to add distant areas to the imaginary geography of the nation. Local, concrete power relations were replaced by the nation state, "quite unlike previous power relations; a wider, more abstract, more enigmatic dominion - that needed a new symbolic form in order to be understood". ${ }^{5}$ Even those who follow Ernest Gellner in stressing the importance of the capitalist market economy for the emergence of nationalism are tapping into the model of accumulation. ${ }^{6}$ The basic model in these theories of the spread of nationalism thus rests on an adding process. By focussing on loss, we may problematize this accumulative model: investigating loss inserts an element of deprivation, of negativity, as fundamental for creating expansion.

Our aim is to explore the notion of loss as a part of nationalisms and nation building in the long nineteenth-century Baltic Sea region. We address multiple aspects of the question of how loss was charged with emotions and set in motion in nationalist discourses and practices. The case studies are diverse both in terms of disciplinary approach and source material: historians, historians of ideas, art historians and historians of literature investigate material from Finland, Estonia, Poland, Germany, Denmark, and Sweden, ranging from political writings, lectures, travel literature, novels, and paintings to "ego-documents" such as letters and diaries. Different scales of loss are thus confronted: the production of loss in public discourse is matched with how loss was experienced, negotiated, used, and enacted related to nationalist practices in people's lives, that is in the lives of people promoting nationalist thought.

Through history, the peoples across the Baltic Sea have affected one another in multiple ways, sharing a wider neighbourhood and a common water way. Ideas, people and goods - not to mention armies - have travelled over the shifting borders. The Baltic Sea region might not be a region in the sense of a shared identity, but there have been all kinds of exchanges and bonds, both tied and severed, over the centuries. ${ }^{7}$ The political origins of the present-day

5 Franco Moretti, Atlas of the European Novel, 1800-19oo (London: Verso, 1998), 17.

6 Ernest Gellner, Nations and Nationalism (Oxford: Blackwell, 1983). For an overview of the impact of Gellner's work, see e.g. Dale J. Stahl, An Analysis of Ernest Gellner's Nations and Nationalism (London: Macat, 2017).

7 Max Engman problematizes the notion of regions in the Baltic Sea area, and notes that different regions have been created throughout the centuries depending on the current most dominant economic and military powers. Max Engman, Ett långt farväl: Finland mellan Sverige och Ryssland efter 1809 (Stockholm: Atlantis, 2009), 52. On the idea of Estonian Nordic identity and regionalism as a dimension of Estonian nineteenth- and early twentieth-century nationalism, see Mart Kuldkepp "The Scandinavian Connection in Early Estonian Nationalism", Journal of Baltic Studies (2013): 1-26, http://dx.doi.org/10.108o/o1629778.2012.744911. 
nation states across the Baltic Sea differ considerably; their political situations during the nineteenth century were vastly different. Parts of Poland, the Baltic States, and Finland (from 1809) were included in the Russian Empire, but with varying degrees of relative autonomy. The Grand Duchy of Finland was anxious to keep its quite extensive autonomy, but the implications for Finnish nationalism in obtaining that objective changed. Russian authorities initially supported the incipient Finnish nationalism in order to cut its former ties with Sweden, whereas the late-nineteenth-century Finnish nationalism had to face Russification campaigns - as indeed Finnish-speaking and Sámi people on the other side of the Swedish border suffered from corresponding campaigns from Swedish authorities. ${ }^{8}$ This is only one example to suggest how shifting political conditions over time and space affected nationalist discourse. Nevertheless, there is a strong convergence in relation to the sense of loss. These discrepancies amount to an interesting case for testing the notion of loss as a focus for analysis, and strengthen the importance of a transnational and crossdisciplinary approach.

We argue that there is an on-going production of loss in nationalist ideology; the production of loss is indeed a distinguishing feature of modern nationalism in contrast to earlier forms of patriotism. In the eighteenth century the traditional patriotic praise of king and state were accompanied by a new ideal of citizenship, emphasising economic and cultural contributions to one's country (cf. Maciej Janowski's and Jens Eike Schnall's chapters in the present volume). The ensuing Romantic nationalism, on the other hand, initiated modern nationalist thought by introducing the idea of a national people connected to a national landscape and defined by a national history, one whose origin was lost and yet essential for the new concept of national identity. ${ }^{9}$ The function of loss in nationalist ideology is in fact an effect of time as

8 See e.g. Lars Elenius, Både finsk och svensk: modernisering, nationalism och språkförändring i Tornedalen 1850-1939 (Umeå: Kulturgräns norr, 2001); Lars Elenius, Nationalstat och minoritetspolitik: samer och finskspråkiga minoriteter $i$ ett jämförande nordiskt perspektiv (Lund: Studentlitteratur, 2006).

9 On the eighteenth-century idea of patriotic citizenship in the Nordic countries, see e.g. Bo Lindberg, Den antika skevheten: Politiska ord och begrepp $i$ det tidig-moderna Sverige (Stockholm: Kungl. Vitterhets Historie och Antikvitets Akademien, 20o6); Jakob Christensson, Lyckoriket: Studier i svensk upplysning (Stockholm: Atlantis, 1996), 105-69; Mikael Alm, Kungsord i elfte timmen: språk och självbild $i$ det gustavianska enväldets legitimtetskamp 1772-1809 (Stockholm: Bokförlaget Atlantis, 2002), 116-30, 319-28; Tine Damsholt, Fcedrelandskcerlighed og borgerdyd: Patriotisk diskurs og militcere reformer i Danmark $i$ sidste del af 1700-tallet (Copenhagen: Museum Tusculanum, 2000). On the distinction between patriotism and nationalism, see Tine Damsholt, "En national turist i det patriotiske landskab", Fortid og Nutid (March 1999): 3-26. 
a defining feature of the nationalist myth. The three-dimensional temporality of nationalism rests on the fantasy of a past that will be re-enacted, thus forming the present to ensure a prosperous future. But in order for the past to be re-enacted, it has to be lost. Nationalist ideology necessarily works through a production of loss. Different losses were charged with different emotions such as nostalgia, grief, melancholy, shame, fear, anger, and revenge - emotions that also changed over time, displacing the function of loss. Nevertheless, to argue that a sense of loss is produced, and thus adopting a constructivist perspective, certainly does not rule out the fact that real losses did occur.

A very real and undisputable loss was the nineteenth-century territorial losses that characterized several of the Baltic Sea region nationalisms. Empires were more or less erased from the map: the final dissolution of the Holy Roman Empire was effectuated in 1806 with the defeat of the Prussian and Saxon troops in Jena and Auerstedt, and the Polish-Lithuanian Commonwealth disappeared with the partitions of Poland between Russia, Prussia and the Habsburg Monarchy, completed in 1795. Denmark and Sweden, the Nordic countries with an imperial past, took their current form during the nineteenth century as a result of territorial losses. These losses have been conceived of as traumatic experiences that instigated nationalism. ${ }^{10}$ Still, shifting borders had been a recurrent experience for the peoples populating the shores of the Baltic Sea for ages past. The pivotal change was nationalist thought, investing the territorial losses with emotions, which is the topic of Maciej Janowski's, Anna Bohlin's and Bjarne Thorup Thomsen's contributions to this volume.

The partition of Poland had repercussions all over Europe, and may be regarded as a foundational trope for territorial loss in nineteenth-century nationalisms in the Baltic Sea region. Poland's fate, the dissolution of the state conceived of as a threat of a vanishing of the nation, echoed in other nationalisms. Conversely, the Polish uprisings were a cause for identifica-

10 For a critical discussion on Denmark's and Sweden's territorial losses in nationalist historiography, see e.g. Rasmus Glenthøj, "Historier om et nederlag", in Konfliktzonen Danmark: stridende fortcellinger om nyere dansk historie, eds. Sissel Bjerrum Fossat, Rasmus Glenthøj and Lone Kølle Martinsen (Copenhagen: Gads Forlag, 2018), 88-115; Henrik Edgren, "Traumakonstruktionen: Svensk historieskrivning om rikssprängningen 18o9", Scandia 76, no. 1 (2010): 9-39; Åke Sandström, "Sökandet efter en ny svensk identitet: Om svensk självsyn och synen på Finland 1808-186o", in Maktens mosaik: Enhet, särart och självbild i det svenska riket, eds. Max Engman and Nils Erik Villstrand (Helsingfors: Svenska litteratursällskapet i Finland, 2008), 381-402; Åke Sandström, "Sveriges 18o9: Föreställningar om finska kriget under 200 år”, in Fänrikens marknadsminne: Finska kriget 1808-1809 och dess följder i eftervärldens ögon, ed. Max Engman (Helsingfors: Svenska litteratursällskapet i Finland \& Stockholm: Bokförlaget Atlantis, 2oog), 27-96. 
tion and evoked intense emotions in all the Nordic countries. While Finnish troops were part of the Russian military campaign repressing the rebellion in 1830, revolutionary Finnish students in Helsinki raised a toast for the Poles in December the same year - a daring action in the Russian Grand Duchy, which caused inquiries and started civil unrest and repressions. ${ }^{11}$ In Sweden and Norway, liberal authors such as the Swedish Carl Fredrik Ridderstad and the Norwegian Henrik Wergeland published poems celebrating the Polish uprisings, whereas the Swedish students demonstrated for liberty and for Poland. ${ }^{12}$ After the defeat, feasts of mourning were arranged in Uppsala to glorify Poland while a giant, blood-red doll portraying the Tsar was hung up in the street. ${ }^{13}$ The territorial loss of one nation had a transnational bearing; the sense of loss was circulated in what Anne-Marie Thiesse has called the "identity trade between nations". 14

Still, territorial loss has had different functions in different nationalisms. The emotions connected to the Swedish loss of Finland in 1809, one-third of the territory, varied considerably during the nineteenth century - a fact that Anna Bohlin addresses in chapter three. Today, the loss of Finland has practically no significance for the Swedish self-image whatsoever. ${ }^{15}$ In a similar vein, the Danish loss of Norway in 1814 was thoroughly lamented in the nineteenth century, among others by the writer Steen Steensen Blicher (1782-1848), whose works Jens Eike Schnall analyses in chapter two. After the nineteenth century, though, the loss of Norway has received little attention, whereas the losses in the Second Schleswig Wars in 1864, on the contrary, remain to this day an important memory site for national self-understanding, which Peter Nørgaard Larsen highlights in chapter five. ${ }^{16}$ Bjarne Thorup Thomsen analyses in chapter six the conflicting nationalist - and anti-nationalist - emotions

11 Johan Wrede, Världen enligt Runeberg: En biografisk och idéhistorisk studie (Helsingfors: Svenska litteratursällskapet i Finland \& Stockholm: Bokförlaget Atlantis, 2005), 169-71, 316; Matti Klinge, Den politiske Runeberg (Helsingfors: Söderströms \& Co. \& Stockholm: Bokförlaget Atlantis, 2004), 145-51. Klinge notes that the Polish Catholicism was a reason for compassion in Catholic France, but had the opposite effect in Lutheran Finland. Klinge, Den politiske Runeberg, 151.

12 See K.G. Fellenius, ed., Polen i svensk lyrik (Stockholm: A.B. Seelig \& Co., 1935); Elin Stengrundet, "Opprørets variasjoner: Autoritetstematikk i fire dikt av Henrik Wergeland" (PhD diss., Høgskolen i Innlandet, 2018).

13 Klinge, Den politiske Runeberg, 148.

14 Anne-Marie Thiesse, "National Identities: A Transnational Paradigm", in Revisiting Nationalism: Theories and Processes, eds. Alain Dieckhoff and Christophe Jaffrelot (New York: Palgrave Macmillan, 2005), 125.

15 Edgren, "Traumakonstruktionen"; Sandström, "Sveriges 1809: Föreställningar om finska kriget under 200 år".

16 Glenthøj, "Historier om et nederlag". 
connected to the loss of Schleswig in late-nineteenth-century Danish literature. Territorial losses are undeniably real, but they have no stable significance and the affective responses vary. The emotionally charged notion of loss is produced by nationalist discourse. The "gaining" sides of territorial conflicts nationalist movements in Finland, Estonia, Latvia, Lithuania, that would proclaim independence at the time of the First World War - still relied on a production of loss, most importantly losses of language and of history, which is the topic of Kristina Malmio's, Eve Annuk's, Heidi Grönstrand's and Tiina Kinnunen's contributions.

The cases analysed in this volume take their point of departure from the current day nation states: we investigate nineteenth-century nationalisms that ended up with statehood. The selection suggests a teleological argument that is unintentional, and anyhow an unhistorical, belated construction; there was no way of knowing in the nineteenth century what the twenty-first-century map of Northern Europe would look like. Nationalist movements took different forms and the concept of the nation had - and still has - different meanings. For instance, the Sámi people form a nation in terms of a national territory, Sápmi, a National Day on the 6th of February, and in terms of political representation, but the nation has no state. The Sámi's nineteenth-century history within the nation-building projects in Finland, Sweden and Norway respectively is a history of loss of territory, language, and traditions, with unspeakable suffering as a consequence. ${ }^{17}$ Sometimes included, though often excluded, the ambivalent position of the Sámi population reveals the different constructions of the nation, as attested by one of the foremost creators of the Finnish people in the nineteenth century, Zacharias Topelius (1818-1898), analysed by Jens Grandell in chapter four. Exclusion as well as inclusion involves losses on all sides. The production of loss in nationalist discourse had material consequences, but in order to affect people's lives and material circumstances, it required a rhetoric with a potential to circulate emotions.

\section{1 \\ Figures of Loss: Sacrifice}

The figures of loss have a long history and were, at the beginning of the nineteenth century, absorbed in the service of the nation. The ultimate loss is to sacrifice your own life. As Tiina Kinnunen notes in chapter thirteen, sacrifice is a gendered concept, most conspicuously in wartime. The intersection 17 See e.g. Elenius, Nationalstat och minoritetspolitik; Elenius, Både finsk och svensk: modern-
isering, nationalism och språkförändring i Tornedalen 1850-1939. 
of bodies, emotions, and politics, places gender at the heart of the mechanisms of the production of loss. The justification for men to lose their lives in battle changed over the nineteenth century, transitioning from earlier ideas of obtaining personal glory to nationalist emotions, mobilizing mass-armies through, in George L. Mosse's words, "the Myth of the War Experience". ${ }^{18}$ This displacement of rationalizations and emotions did not happen over-night. For example, incipient nationalist feelings did not yet rule out other allegiances in 1830: the Finnish military who participated in the Russian army field train in Poland combined the idea of fighting for the Finnish nation and the Russian Empire simultaneously ${ }^{19}$ But wartime also affected women, first and foremost by the loss of male members of their families.

"Who did not lose someone they loved in this rich harvest of death?" the German writer Amalie von Helvig (1776-1831) asked in her pamphlet $A n$ Deutschlands Frauen: Von Einer ihrer Schwestern (To Germany's Women: From One of Their Sisters, 1814) after the battle of Leipzig in $1813 .{ }^{20}$ Jules Kielmann points out in chapter ten that Helvig immediately turned the memory of the sacrifices into a generative promise of a better future: "Thus shall our joy be solemn, and our pain fruitful; otherwise, we truly would not deserve to feel either". ${ }^{21}$ Kielmann analyses how Helvig used war sacrifices to define gender, citizenship and national identity through grief, shame, fear and pride. Narratives of war in peacetime also provided an incentive to intensify imagining

18 Mosse investigates nationalism as a civic religion and places the First World War cult of the fallen soldiers as its center: "The Myth of the War Experience was designed to mask war and to legitimize the war experience; it was meant to displace the reality of war. The Memory of the war was refashioned into a sacred experience which provided the nation with a new depth of religious feeling, putting at its disposal ever-present saints and martyrs, places of worship, and a heritage to emulate". George L. Mosse, Fallen Soldiers: Reshaping the Memory of the World Wars (New York \& Oxford: Oxford University Press, 1990), 7. See also Stefan Dudink, Karen Hagemann, and John Tosh, eds., Masculinities in Politics and War: Gendering Modern History (Manchester \& New York: Manchester University Press, 2004); Ida Blom, Karen Hagemann, and Catherine Hall, eds., Gendered Nations: Nationalisms and Gender Order in the Long Nineteenth Century (Oxford \& New York: Berg, 2000); Hugo Nordland, Känslor i krig: Sensibilitet och emotionella strategier bland svenska officerare 1788-1814 (Lund: Agerings bokförlag, 2015). On the cult of the national authors as incarnations of the national soul; a transference of the religious sphere to the cultural, see Anne-Marie Thiesse, La fabrique de l'écrivain national: Entre littérature et politique (Paris: Éditions Gallimard, 2019), 13, 156-92.

19 Jussi Jalonen, On Behalf of the Emperor, On Behalf of the Fatherland: Finnish Officers and Soldiers of the Russian Imperial Life-Guard on the Battlefields of Poland, 1831 (Leiden \& Boston: Brill, 2015); Engman, Ett långt farväl, 222-25. On "building the Myth", see also Mosse, Fallen Soldiers, 15-50.

20 Amalie von Helvig quoted in Jules Kielmann's chapter in the present volume.

21 Amalie von Helvig quoted in Jules Kielmann's chapter in the present volume. 
the nation and the good citizen - and an opportunity to allow women to take a more active role in the absence of men. Kristina Malmio discusses in chapter seven the war as a backdrop in the Finnish author Fredrika Runeberg's (1807-1879) historical novel Fru Catharina Boije och hennes döttrar: en berättelse från stora ofredens tid (Lady Catharina Boije and her Daughters: A Story from the Time of the Greater Wrath, 1858), set during the Great Northern War at the beginning of the eighteenth century.

However, the trope of sacrifice is not restricted to losing lives for the country. In chapter twelve, Eve Annuk draws attention to loss construed as a sacrifice of love in order to gain national self-respect in her investigation of the short story "Liina" (1877) by the first Estonian feminist, Lilli Suburg (1841-1923). The title character chooses to marry an Estonian man instead of a German man, which amounts to a double loss. She sacrifices her personal love for the German and also her possibilities for personal freedom in terms of social climbing, motivated by love for the nation, understood as a national landscape and identification with other social classes based on language. A corresponding case of sacrifice of language, though under different political circumstances, is offered by Heidi Grönstrand in chapter eleven on the life and works of Evald Ferdinand Jahnsson (1844-1895), a lesser-known Finnish writer with roots outside the educated class. He actively promoted Finnish language and literature and supported the Finnish-language movement of the 188 os. The process of becoming a Finnish language writer was not uncomplicated; Jahnsson had difficulties in abandoning Swedish, but the Finnish-language movement required a disengagement from Swedish. Grönstrand's view is inspired by theories, which approach nationality and nation building from below, from an everyday perspective. ${ }^{22}$

The concept of sacrifice was in the nineteenth century still firmly anchored in a religious discourse. To acknowledge that is not necessarily to argue that nationalism is a secularized religion - that may or may not be the case - but it is to claim that nationalist discourse in the early nineteenth century was articulated through Christian figures of thought and understood in relation to a Christian concept of evolution. The Messianic time is clearly the model for the three-dimensional temporality of nationalism, and Christian salvation history did make sense of sacrifice.$^{23}$ Christian beliefs were also used to legitimize nationalism by many nineteenth-century nationalist thinkers including

22 Marco Antonsich and Michael Skey, "Introduction: The Persistence of Banal Nationalism", 4-6; Billig, Banal Nationalism.

23 Anna Bohlin and Ragnhild Johnsrud Zorgati, "Tracing the Jerusalem Code c.1750-c.1920: The Christian Storyworld Expanded and Fragmented", in Tracing the Jerusalem Code III. The Promised Land: Christian Cultures in Modern Scandinavia (ca. 1750-ca. 1920), eds. Ragnhild J. Zorgati and Anna Bohlin (Berlin: Walter de Gruyter, 2021), 12-50. 
Steen Steensen Blicher (chapter two), Fredrika Bremer (1801-1865, chapter three), Zacharias Topelius (chapter four) - and were still significant to an early twentieth-century feminist such as Alexandra Gripenberg (1857-1913, chapter thirteen). All Nordic nationalisms in the nineteenth century apprehended the Lutheran faith as a core characteristic of the nation, which entailed a whole range of problems, given that the supposed origin of the nations was located in a heathen past, and that the many centuries of Catholicism had to be accounted for in some way. ${ }^{24}$ The zealous Lutheranism occasionally heightened to vocational nationalism, that is the idea that the nation in question was chosen by God to safeguard the true faith (Lutheranism) from the Orthodox Church in the East and the Roman-Catholic Church in the South. ${ }^{25}$ The Catholic South was no better in that respect: some Polish nationalists likewise entertained a notion of constituting a chosen nation. ${ }^{26}$

In chapter one, Maciej Janowski shows how not only Biblical, but also Classical Roman references structured the experience of loss in Poland at the turn of the nineteenth century. As Janowski notes, "a very traditional, classical

24 Peter Aronsson, Narve Fulsås, Pertti Haapala and Bernhard Eric Jensen, "Nordic National Histories", in The Contested Nation: Ethnicity, Class, Religion and Gender in National Histories, eds. Stefan Berger and Chris Lorenz (New York \& Basingstoke: Palgrave Macmillan, 2008), 256-82; Pertti Anttonen, "Oral Traditions and the Making of the Finnish Nation", in Folklore and Nationalism in Europe During the Long Nineteenth Century, eds. Timothy Baycroft and David Hopkin (Leiden \& Boston: Brill, 2012), 325-5o.

25 Matti Klinge, Idyll och hot: Zacharias Topelius - hans politik och idéer, trans. Nils Erik Forsgård (Helsingfors: Söderström \& Co. \& Stockholm: Atlantis, 200o) 28, 256; Wrede, Världen enligt Runeberg, 19o; Alf Tergel, "Ungkyrkorörelsen och nationalismen", in Kyrka och nationalism i Norden: Nationalism och skandinavism i de nordiska folkkyrkorna under 180o-talet, ed. Ingmar Brohed (Lund: Lund University Press, 1998), 343-55; Urban Claesson, Folkhemmets kyrka: Harald Hallén och folkkyrkans genombrott. En studie av socialdemokrati, kyrka och nationsbygge med särskild hänsyn till perioden 1905-1933 (Uppsala: Uppsala University, 2004), 105-06; Jes Fabricius Møller, "Grundtvig, Danmark og Norden”, in Skandinavismen: Vision og virkning, eds. Ruth Hemstad, Jes Fabricius Møller, and Dag Thorkildsen (Odense: Syddansk Universitetsforlag, 2018), 99-120; Dag Thorkildsen, "For Norge, kjempers fødeland' - norsk nasjonalisme, skandinavisme og demokrati i det 19. århundre", in Kyrka och nationalism i Norden: Nationalism och Skandinavism $i$ de nordiska folkkyrkorna under 180o-talet, ed. Ingmar Brohed (Lund: Lund University Press, 1989), 129-55. See also Anthony D. Smith, "Biblical beliefs in the shaping of modern nations", Nations and Nationalism 21 no. 3 (2015): 403-22; Anthony D. Smith, Chosen Peoples: Sacred Sources of National Identity (Oxford: Oxford University Press, 2003).

26 Klinge, Idyll och hot, 71; cf. Maciej Janowski, "A Marriage of Convenience: The Roman Catholic Church and Modernity in Nineteenth-Century Europe", Kwartalnik Historyczny CXXIV (2017): 43-9o, http://dx.doi.org/10.12775/KH.2017.124.SI.2.o2. 
imagery was instrumental in bringing about an essentially new, and intrinsically modern concept of nation". ${ }^{27}$ The partition of Poland in 1795 occurred at a time when the concepts of "nation", "state" and "citizen" did not yet have stable meanings; what was actually lost remained an open question to the political elite. Virgil's Aeneid provided a language with which to conceive of the loss of a homeland, and how it may be preserved in exile. In 1797, the Polish author Józef Wybicki (1747-1822) interpreted the Penates, the urban deities that Aeneas rescued, as the Poles themselves in a song that subsequently became the Polish national anthem. In Janowski's words: "Re-reading their Aeneid, the Poles understood that their nation still exists". ${ }^{28}$ Furthermore, a sentimental mode of mourning predated and shaped the construction of territorial loss, just as James Macpherson's Ossian poems, published in the $176 \mathrm{os}$, informed among many others the Danish Blicher's nationalist writings, discussed by Jens Eike Schnall in chapter two. ${ }^{29}$ Figures of loss, such as sacrifice and exile, and literary tropes for grief formed nationalist emotions, established and circulated in public discourse. Literature and art were powerful means of making - in Sara Ahmed's phrase - emotions "stick" to certain objects, bodies, and memories, ${ }^{30}$ but for these emotions to mobilize mass-movements, they had to affect the individual.

\section{$2 \quad$ Scales of Loss: Emotional Communities and Personal Feelings}

The idea of national loss implies the individual's identification with the nation as an "imagined community". However, our material indicates that personal losses, such as losing a child, frequently tapped into collective notions of loss, thus bringing about a re-evaluation by integration into a nationalist discourse of home and belonging. That was the case for both Amalie von Helvig at the beginning of the nineteenth century (chapter ten) and for the Swedish artist Carl Larsson (1853-1919, chapter eight) a hundred years later. Amalie

\footnotetext{
27 Maciej Janowski, "Ex ossibus ultor: Virgil, Ezekhiel and the Transformation of the Polish National Idea after 1795", in Multiple Antiquities, Multiple Modernities: Ancient Histories in Nineteenth History European Cultures, eds. Gabor Klaniczay, Michael Werner, and Ottó Gecser (Frankfurt \& New York: Campus Verlag, 2011), 538.

28 Janowski, "Ex Ossibus Ultor", 536.

29 On the impact of Ossian in European nation building processes, see Thiesse, La fabrique de l'écrivain national, 33-130.

30 Sara Ahmed, The Cultural Politics of Emotion (Edinburgh: Edinburgh University Press, [2004] 2014).
} 
von Helvig lost a child during her stay in Sweden, which contributed to her shifting emotional affiliation and idea of a "fatherland" between Germany and Sweden. Carl Larsson, on the other hand, as discussed by Martin Olin in chapter eight, invested the despair surrounding his son's death into a nostalgic representation of vanishing agricultural traditions and landscapes - and also into contempt and sarcasm for the loss of Sweden's personal union with Norway in 1905, as well as for the massive loss of population due to migration to the United States. The affective effort of nationalist discourse in forming identity politics clearly works both ways in bridging the individual experiences and cultural politics. Nationalist discourse produces loss motivating personal sacrifices, and simultaneously offers the means by which to assign significance to other kinds of personal losses, thereby accumulating emotional capital in the nationalist construction of loss, in Ahmed's terminology.

Nationalist emotions are the object of phenomenologist Sara Ahmed's influential study The Cultural Politics of Emotion. Ahmed analyzes how fear, hate, and love, are part of the "affective economies" that establish nationalist ideas. ${ }^{31}$ Feminist research investigating emotions has mainly worked on contemporary material, and Ahmed is no exception. ${ }^{32}$ Feelings, Ahmed argues, circulate in social contexts, attach to different bodies and objects, charge them and accumulate - in that sense, emotions work as capital. ${ }^{33}$ Since Ahmed's theory is relying on rhetoric, it has proven useful in unveiling how emotions charge the nationalist production of loss in nineteenth-century texts. For instance, Kristina Malmio asks which "exchanges and transfers take place" in the affective economy constituted in Fredrika Runeberg's historical novel.

Feelings are indeed personal, but the individual experience depends on collective and cultural norms changing over time, connected to gender and social class - emotionology in Peter and Carol Stearns' classic article. ${ }^{34}$ Historian

31 Ahmed, The Cultural Politics of Emotion.

32 E.g. Marianne Liljeström and Susanna Paasonen, eds., Working with Affect in Feminist Readings: Disturbing Differences (London \& New York: Routledge, 2010); Annelie Bränström Öhman, Maria Jönsson, and Ingeborg Svensson, eds., Att känna sig fram: Känslor i humanistisk genusforskning (Umeå: h:ström - Text \& Kultur, 2011). The anthology Loss: The Politics of Mourning also deals only with twentieth-century and contemporary material. David L. Eng and David Kazanjian eds., Loss: The Politics of Mourning (Berkeley, Los Angeles \& London: University of California Press, 2003).

33 Ahmed, The Cultural Politics of Emotion. Cf. Rob Boddice, The History of Emotions (Manchester: Manchester University Press, 2018), 183-84.

34 Peter N. Stearns and Carol Z. Stearns, "Emotionology: Clarifying the History of Emotions and Emotional Standards", The American Historical Review 9o, no. 4 (October 1985): $813-36$. 
Barbara H. Rosenwein has coined the term emotional communities to conceptualise how groups are bounded by "particular values, modes of feeling, and ways to express those feelings". ${ }^{35}$ Different emotional communities may indeed overlap; the notion may refer to an entire social class at a specific moment in time or smaller groups - a family, a congregation, a social movement - constituting emotional communities of their own. ${ }^{36}$ Even though nationalist thinkers did not succeed in transforming the nation into an emotional community that was undoubtedly their goal. Rosenwein notes in Generations of Feeling: A History of Emotions, 600-1700, that in dealing with historical material, there is no way to separate feeling from rhetoric, in fact, "emotional expression is always rhetorical to some degree". 37 Therefore the distinctions between the concepts of affects, feelings and emotions have no bearing on historical material. ${ }^{38}$

The Finnish-minded Fennoman community, originally mainly Swedishspeaking, exemplifies one type of emotional community with a focus on duty in nineteenth- and early twentieth-century Finland - the elite was expected to civilize Finnish-speaking ordinary people. The chapter on the Fennoman feminist Alexandra Gripenberg by Tiina Kinnunen shows how Gripenberg lost her faith in the proper development of the Finnish nation due to the rising working class. After having invested heavily in promoting the Finnish language and the working class, their different values were demonstrated in particular in the revolutionary events of 1905, which made Gripenberg disillusioned. Furthermore, she felt that she had personally sacrificed too much, amongst other things her own identity as a Swedish-speaking person. In her case, the nationalist cause did not in the end motivate personal sacrifices. The Fennoman vision of an exclusively Finnish-speaking Finland posed a threat to the future of the Swedish language and culture in the country. This loss at a national level was, however, a vision to which Gripenberg could give a regenerative meaning.

35 Barbara H. Rosenwein, Generations of Feeling: A History of Emotions, 600-1700 (Cambridge: Cambridge University Press, 2016), 3.

$3^{6}$ Rosenwein, Generations of Feeling, 3.

37 Rosenwein, Generations of Feeling, 9.

38 Rosenwein, Generations of Feeling, 7. The authors of Emotions and Everyday Nationalism in Modern European History agree: "a rigid separation of discourse and affect renders written and spoken texts, narratives and other familiar objects of qualitative social research useless". Andreas Stynen, Maarten van Ginderachter, and Xosé M. Núñez Seixas, "Introduction: Emotions and everyday nationalism in modern European history", 1-15. Neither does Ahmed distinguish between "emotions" and "affects", see Ahmed, The Cultural Politics of Emotions, 5-6. For a thorough discussion of the terminology of the history of emotions, see Boddice, The History of Emotions. 
It comes as no surprise that the things lost in nationalist discourse were displaced from early Romantic nationalist thought at the beginning of the nineteenth century to the turn of the twentieth century on the verge of the First World War. A hundred years of industrialisation, European imperialism and migration had changed the historical circumstances. Nationalist thought developed and so did the production of loss. Not only did lost Viking virtues go out of fashion to be replaced by loss of equality and justice; the ideas of loss connected to the very same objects were displaced. The national landscape for instance, a foundational element of nationalist thought, was inscribed with different kinds of loss and shifting emotions throughout the nineteenth century. The Danish national landscape may illustrate this point.

Jens Eike Schnall shows how the Danish landscape in Blicher's nationalist writings was in fact the sublime Ossian landscape, transposed from Macpherson's poems to the Danish soil, imbued with melancholy. The Danish territory is actually peopled both on and underneath the earth, as the characters in the story Røverstuen (The Robbers' Den) from 1827 live in a burial mound; the living and the dead ancestors occupy the same space inside the earth in a depiction of a lost harmonious community. A couple of decades later, though, the idyllic landscape provided an escape precisely from death. The cholera pandemic hit Copenhagen hard in 1853; it offers a historical perspective on the present-day corona pandemic. Peter Nørgaard Larsen argues in chapter five that the pandemic had a decisive impact on the idyllic and nostalgic framing of the Danish national landscape paintings in the following years. His inquiry into the specific conditions for the creation of lively Arcadian landscapes reveal an overcrowded Copenhagen plagued by a deadly disease as the background against which a dream of a lost, near past, barred by a pandemic, appear. Bjarne Thorup Thomsen studies the national landscape in Danish literature of the second half of the nineteenth century, and discovers a landscape increasingly embedded with more complex emotions. H.C. Andersen's De to Baronesser (The Two Baronesses, 1848) reflects the Danish geopolitics in the ongoing First Schleswig War, although the hybridity of the borderlands is celebrated, whereas the territorial loss in the Second Schleswig War has more complicated effects in Herman Bang's authorship at the turn of the twentieth century. The borderlands engender a critique of the loss of morals as a consequence of war, and the celebration of hybridity now mounts to a critique of exclusionary, inward-facing nationalism. Loss is constant, even though the emotions and the elements lost have exchanged. 
Another case in point is the national people, a central category of nationalist discourse - and probably the most debated category in the nineteenth century as well as today. The exclusionary nature of the idea of a national people has repeatedly led to disasters; the many forms of exclusionary mechanisms range from laws to feelings. An important theme in this anthology is the emotional construction of different kinds for criteria for exclusion: Eve Annuk highlights language as the excluding mechanism in Estonian nationalism, while the language strife in Finland amounted to a complex history of personal sacrifices and collective losses, as is shown in Heidi Grönstrand's and Tiina Kinnunen's chapters. Topelius' unwillingness to conceive of the nation in terms of language precisely because he wanted to include both Finnish and Swedish in the Finnish nation, as discussed by Jens Grandell, made it impossible for him to use language as an exclusionary criterium for the Sámi people, and instead settled for nomadism. However, the actively affected losses constructing national peoples that shifted over time and place are only one aspect of changing productions of loss with regard to the people.

The peasant was closely connected to the notion of the people in nationalist discourse, but the function of the peasant changed radically over the nineteenth century, which had an impact on ideas and experiences of loss. The people as the subject of the narrative of the nation was displaced - as Anne-Marie Thiesse notes: "The cultural integration of the people into the national community prefigures and invokes the political integration". ${ }^{39}$ In the early nineteenth century, the peasant was understood as a carrier of lost traditions, folk beliefs and languages, while the peasant in the late nineteenth century was becoming an aesthetic ideal - a motif for Carl Larsson to preserve, in Martin Olin's words in chapter eight, as "the updated mythos of the peasant as the incarnation of a national spirit". However, by the late nineteenth century, the peasant had also become a political power base. The latter would in fact expose the loss of an imagined community - at least for Alexandra Gripenberg in Tiina Kinnunen's analysis. The people's legitimizing power shifted from a subject of history to a subject of representational politics, which

39 "L'intégration culturelle du peuple dans la communauté nationale préfigure et appelle son intégration politique". Thiesse, La fabrique de l'écrivain national, 55. Homi K. Bhabha points out in "DissemiNation" that "the people" functions simultaneously as the subject of the narrative of the nation and the object of nationalist pedagogy, which leads to a paradoxical temporality structuring nationalist discourse, but our argument concerns another temporal aspect: a displacement of the subject position of the people in the narrative of the nation. Cf. Homi K. Bhabha, "DissemiNation: Time, Narrative, and the Margins of the Modern Nation", in Nation and Narration, ed. Homi K. Bhabha (London: Routledge, 1990), 291-322. 
turned out to be something else entirely in terms of loss. The anthology tracks this displacement not only in Sweden, but also in Poland (Maciej Janowski's chapter), Estonia (Eve Annuk's chapter), and Finland (Kristina Malmio's and Heidi Grönstrand's chapters). The late-nineteenth-century nationalist understanding of peasant culture shows yet another paradoxical feature in establishing the Orient as a counter-image by producing loss in an opposite way, which Jenny Bergenmar discusses in chapter nine. The nostalgia for the national agricultural landscape, vanishing in the wake of industrialism, was countered by imagining the Oriental society as traditional, lacking in industry. Imperialist discourse thus conceived of two opposing losses, charged with contradicting emotions, to be mutually filled in by each other.

Finally, the metaphors for imagining the nation, and most specifically the people, changed with implications for the production of loss. Corporeal metaphors have proved to be particularly important for how loss was articulated. Portraying nations as family relations were not unusual at the beginning of the nineteenth century. For instance the Finnish poet Frans Michael Franzén depicted in 1809 (when the war between Sweden and Russia was still on-going) Finland as an orphan "child of the East", taken into custody by the generous foster-father Russia. ${ }^{40}$ However, as several of the contributions show (chapters three, six, seven and twelve), the nineteenth-century novel elaborated on that imagery, on the one hand by means of fictive characters representing nations or discussing national identity, and on the other hand by imagining the national territory as a body, vulnerable, bleeding, raped (chapters six and seven). The novelistic treatment of the corporeal metaphor endowed the nation as body with an inner life. At the turn of the century, Carl Larsson portrayed a real family and a real home - his own - as an exemplary national family, as Martin Olin points out. The financial success of IKEA, which has adopted a lot of aesthetic inspiration from Karin and Carl Larsson's home, has secured a prevailing influence on the idea of Swedish aesthetics; it is fair to say that the Larsson family still occupy the same position in Swedish nationalist discourse. However, to the early nineteenth century understanding of nations

$40 \quad$ Klinge, Den politiske Runeberg, 42. Cf. Pär Alexandersson and Johanna Valenius who have studied the Swedish and Finnish personifications of the respective nations. Alexandersson shows that it was not until the nineteenth century that the seventeenth- and eighteenth-century heraldic Svea became a national mother, whereas Valenius traces the development of the sexually vulnerable Maiden of Finland in the nineteenth century. Pär Alexandersson, Moder Sveas historia: Den svenska nationspersonifikationen under fem sekler (Stockholm: Förlag BoD, 2017), 107-55; Johanna Valenius, Undressing the Maid: Gender, Sexuality and the Body in the Construction of the Finnish Nation (Helsinki: The Finnish Literature Society, 2004). 
as family relations, a real exemplary national family on public display would be unthinkable. Apparently, the corporeal metaphors have transformed over a hundred years and acquired real flesh and blood.

Focussing on loss is a new analytical point of departure within research on nationalism, and the anthology will therefore map out different themes in relation to three lines of inquiry, indicated by the structure of the book. The first part investigates how the production of loss organises thought. Maciej Janowski's chapter "Loss, Emotion, and Transformation of a National Idea: Poland $1795^{-1815^{\prime}}$ and Jens Eike Schnall's "Visions of the Nation and Feelings of Loss in the Works of Steen Steensen Blicher" analyse how earlier literary expressions of loss were claimed and incorporated into nationalist agendas; loss as a pre-existing rhetorical figure was re-connected to other objects and sites. Anna Bohlin addresses how different emotions, changing over time, constructed the perception of territorial loss in "Neglect, Grief, Revenge: Finland in Swedish Nineteenth-Century Literature". The production of loss may also organise nationalist thinking by explicitly excluding - and simultaneously mourning - an entire culture from the nationalist narrative, as Jens Grandell shows in "How a Culture Was Almost Lost: The Sámi in Nineteenth-Century Conceptualisations of Finnish Nationhood". The contributions in the first part of this volume will thus uncover mechanisms at work in the production of loss.

The second part studies how landscapes and bodies become sites for the production of loss. Two contributions examine different aspects of the landscape in Danish culture of the second half of the nineteenth century. Peter Nørgaard Larsen's chapter "Entrenchments and Escape Routes: Expressing a Sense of Loss in Danish Art 1848-1864" analyses the nostalgia of nationalist landscape paintings, whereas Bjarne Thorup Thomsen shows how islands provide the imagery for representing conflicting emotions connected to the nation in "Outreach, Invasion, Displacement: Denmark's Disputed Southern Borderland as Negotiated through Strategic and Affective Aspects of Space in Novels by Andersen and Bang". Kristina Malmio's chapter "Affective Bodies on the Move: Space, Emotions and Loss in Fredrika Runeberg's Historical Novel Lady Catharina Boije and her Daughters" investigates how the depiction of the nation as a bleeding, wounded body deprived of protection increases the emotional investment. The objects and phenomena connected to loss changed over time, as did the emotions that were activated by loss. By 1900 the agrarian 
culture connected to an enchanted world-view were widely perceived as being lost to modernity. Two contributions, Martin Olin's “Carl Larsson's Spadarfvet, My Little Farmstead: Paradise Regained or Lament for a Disappearing Agrarian Society?" and Jenny Bergenmar's "Sweden and Algeria in the Travel Writing of Anna Maria Roos, 1905-1909", study how these fantasies were politically informed and played out in an Algerian setting and in the Swedish countryside, respectively.

Finally, the third part concerns lived nationalism and individual agency. The material in this part mainly consists of letters and diaries, but also of literature on personal loss caused by, or feeding into, nationalist movements. Jules Kielmann's contribution, “Thus Shall our Joy be Solemn, and our Pain Fruitful': Nation, Loss and the Power of Emotions in Amalie von Helvig's Writings", analyses the grief for a lost child leading to expanding the homeland to a transnational project, while Heidi Grönstrand, on the other hand, studies loss of language turned into creativity in "The Sense of Loss in the Context of Language Disputes in Finland: Reflections on E.F. Jahnsson's Authorship". Eve Annuk discusses the demand to give up a love relationship for the love of the nation in "Nationalism, Emotions and Loss in Lilli Suburg's Short Story 'Liina". The emotional sequence in all these cases invariably turns bereavement into positively loaded agency. The last contribution, "Alexandra Gripenberg and Lost Faith in National Belonging", by Tiina Kinnunen provides an example of the exception to this rule: coping with the loss of the fantasy of national unity has no positive outcomes. Still, the production of loss continues to structure the nationalist project in people's conflicting emotions.

\section{Bibliography}

Ahmed, Sara. The Politics of Emotion, 2nd edition. Edinburgh: Edinburgh University Press, [2004] 2014.

Alexandersson, Pär. Moder Sveas historia: Den svenska nationspersonifikationen under fem sekler. Stockholm: BoD, 2017 .

Alm, Mikael. Kungsord i elfte timmen: språk och självbild i det gustavianska enväldets legitimitetskamp 1772-1809. Stockholm: Bokförlaget Atlantis, 2002.

Anderson, Benedict. Imagined Communities: Reflections on the Origin and Spread of Nationalism, revised edition. London: Verso, 2006.

Antonsich, Marco and Michael Skey. "Introduction:The Persistence of Banal Nationalism". In Everyday Nationhood. Theorising Culture, Identity and Belonging after Banal Nationalism, edited by Michael Skey and Marco Antonsich, 1-13. London: Palgrave Macmillan, 2017. 
Anttonen, Pertti. "Oral Traditions and the Making of the Finnish Nation". In Folklore and Nationalism in Europe During the Long Nineteenth Century, edited by Timothy Baycroft and David Hopkin, 325-5o. Leiden \& Boston: Brill, 2012.

Aronsson, Peter, Narve Fulsås, Pertti Haapala, and Bernhard Eric Jensen. "Nordic National Histories". In The Contested Nation: Ethnicity, Class, Religion and Gender in National Histories, edited by Stefan Berger and Chris Lorenz, 256-82. New York \& Basingstoke: Palgrave Macmillan, 2008.

Bhabha, Homi K. "DissemiNation: Time, Narrative, and the Margins of the Modern Nation". In Nation and Narration, edited by Homi K. Bhabha, 291-322. London: Routledge, 1990.

Billig, Michael. Banal Nationalism. London: Sage, 1995.

Blom, Ida, Karen Hagemann and Catherine Hall, eds. Gendered Nations: Nationalisms and Gender Order in the Long Nineteenth Century. Oxford \& New York: Berg, 2000.

Boddice, Rob. The History of Emotions. Manchester: Manchester University Press, 2018. Bohlin, Anna. "The Novel Reconsidered: Emotions and Anti-Realism in Mid-19thCentury Scandinavian Literature". Nations and Nationalism (published in early view 2021). https://doi.org/10.1111/nana.12698.

Bohlin, Anna and Ragnhild Johnsrud Zorgati. "Tracing the Jerusalem Code c.1750c.1920: The Christian Storyworld Expanded and Fragmented". In Tracing the Jerusalem Code III. The Promised Land: Christian Cultures in Modern Scandinavia (ca. 1750-ca. 1920), edited by Ragnhild J. Zorgati and Anna Bohlin, 12-50. Berlin: Walter de Gruyter, 2021.

Bränström Öhman, Annelie, Maria Jönsson, and Ingeborg Svensson, eds. Att känna sig fram: Känslor i humanistisk genusforskning. Umeå: h:ström - Text \& Kultur, 2011.

Christensson, Jakob. Lyckoriket: Studier i svensk upplysning. Stockholm: Atlantis, 1996.

Claesson, Urban. Folkhemmets kyrka: Harald Hallén och folkkyrkans genombrott. En studie av socialdemokrati, kyrka och nationsbygge med särskild hänsyn till perioden 1905-1933. Uppsala: Uppsala University, 2004.

Damsholt, Tine. Fæedrelandskcerlighed og borgerdyd: Patriotisk diskurs og militcere reformer $i$ Danmark i sidste del af 1700-tallet. København: Museum Tusculanum, 2000.

Damsholt, Tine. "En national turist i det patriotiske landskab". Fortid og Nutid (March 1999): 3-26.

Dudink, Stefan, Karen Hagemann, and John Tosh, eds. Masculinities in Politics and War: Gendering Modern History. Manchester: Manchester University Press, 2004.

Edgren, Henrik. "Traumakonstruktionen: Svensk historieskrivning om rikssprängningen 18o9". Scandia 76, no. 1 (2010): 9-39.

Eiranen, Reetta. Lähisuhteet ja nationalismi: Aate, tunteet ja sukupuoli Tengströmin perheessä 180o-luvun puolivälissä. Tampere: Tampereen yliopiston väitöskirjat 79, 2019 . 
Elenius, Lars. Nationalstat och minoritetspolitik: samer och finskspråkiga minoriteter $i$ ett jämförande nordiskt perspektiv. Lund: Studentlitteratur, 2006.

Elenius, Lars. Både finsk och svensk: modernisering, nationalism och språkförändring $i$ Tornedalen 1850-1939. Umeå: Kulturgräns norr, 2001.

Eng, David L. and David Kazanjian, eds. Loss: The Politics of Mourning. Berkeley, Los Angeles \& London: University of California Press, 2003.

Engman, Max. Ett långt farväl: Finland mellan Sverige och Ryssland efter 1809. Stockholm: Atlantis, 2009.

Fellenius, K.G. ed. Polen i svensk lyrik. Stockholm: A.B. Seelig \& Co., 1935.

Gellner, Ernest. Nations and Nationalism. Oxford: Blackwell, 1983.

Glenthøj, Rasmus. "Historier om et nederlag". In Konfliktzonen Danmark: stridende fortcellinger om nyere dansk historie, edited by Sissel Bjerrum Fossat, Rasmus Glenthøj and Lone Kølle Martinsen, 88-115. Copenhagen: Gads Forlag, 2018.

Hroch, Miroslav. "From National Movement to the Fully-formed Nation: The Nationbuilding Process in Europe". In Mapping the Nation, edited by Gopal Balakrishnan, 78-97. New York and London: Verso, 1996.

Jalonen, Jussi. On Behalf of the Emperor, On Behalf of the Fatherland: Finnish Officers and Soldiers of the Russian Imperial Life-Guard on the Battlefields of Poland, 1837. Leiden \& Boston: Brill, 2015.

Janowski, Maciej. "Ex ossibus ultor: Virgil, Ezekhiel and the Transformation of the Polish National Idea after 1795". In Multiple Antiquities, Multiple Modernities: Ancient Histories in Nineteenth History European Cultures, edited by Gábor Klaniczay, Michael Werner and Ottó Gecser, 527-46. Frankfurt \& New York: Campus Verlag, 2011.

Janowski, Maciej. "A Marriage of Convenience: The Roman Catholic Church and Modernity in Nineteenth-Century Europe". Kwartalnik Historyczny CXXIV (2017): 43-90, http://dx.doi.org/10.12775/KH.2017.124.SI.2.o2.

Kaljundi, Linda, Eneken Laanes, and Ilona Pikkanen, eds. Novels, Histories, Novel Nations: Historical Fiction and Cultural Memory in Finland and Estonia. Helsinki: The Finnish Literature Society, 2015.

Klinge, Matti. Idyll och hot: Zacharias Topelius - hans politik och idéer. Translated by Nils Erik Forsgård. Helsingfors: Söderström \& Co \& Stockholm: Atlantis, 2000.

Klinge, Matti. Den politiske Runeberg. Helsingfors: Söderströms \& Co. \& Stockholm: Atlantis, 2004.

Kuldkepp, Mart. "The Scandinavian Connection in Early Estonian Nationalism". Journal of Baltic Studies (2013):1-26, http://dx.doi.org/10.108o/01629778.2012.744911.

Leerssen, Joep. National Thought in Europe: A Cultural History. Amsterdam: Amsterdam University Press, 2006.

Liljeström, Marianne and Susanna Paasonen, eds. Working with Affect in Feminist Readings: Disturbing Differences. London \& New York: Routledge, 2010. 
Lindberg, Bo. Den antika skevheten: Politiska ord och begrepp i det tidig-moderna Sverige. Stockholm: Kungl. Vittterhets Historie och Antikvitets Akademien, 2006.

Mehtonen, P.M. and Matti Savolainen, eds. Gothic Topographies: Language, Nation Building and "Race". Farnham: Ashgate, 2013.

Møller, Jes Fabricius. "Grundtvig, Danmark og Norden”. In Skandinavismen: Vision og virkning, edited by Ruth Hemstad, Jes Fabricius Møller, and Dag Thorkildsen, 99-120. Odense: Syddansk Universitetsforlag, 2018.

Moretti, Franco. Atlas of the European Novel, 180o-19oo. London: Verso, 1998.

Mosse, George L. Fallen Soldiers: Reshaping the Memory of the World Wars. New York \& Oxford: Oxford University Press, 1990.

Nordland, Hugo. Känslor i krig: Sensibilitet och emotionella strategier bland svenska officerare 1788-1814. Höör: Agerings bokförlag, 2015.

Rosenwein, Barbara H. Generations of Feeling: A History of Emotions, 60o-1700. Cambridge: Cambridge University Press, 2016.

Sandström, Åke. "Sökandet efter en ny svensk identitet: Om svensk självsyn och synen på Finland 1808-186o". In Maktens mosaik: Enhet, särart och självbild i det svenska riket, edited by Max Engman and Nils Erik Villstrand, 381-402. Helsingfors: Svenska litteratursällskapet i Finland, 2008.

Sandström, Åke. "Sveriges 18og: Föreställningar om finska kriget under 200 år”. In Fänrikens marknadsminne: Finska kriget 1808-1809 och dess följder $i$ eftervärldens ögon, edited by Max Engman, 27-96. Helsingfors: Svenska litteratursällskapet i Finland \& Stockholm: Bokförlaget Atlantis, 2009.

Sanz, Amelia, Francesca Scott, and Suzan van Dijk. eds. Women Telling Nations. Amsterdam \& New York: Rodopi, 2014.

Smith, Anthony D. Chosen Peoples: Sacred Sources of National Identity. Oxford: Oxford University Press, 2003.

Smith, Anthony D. The Nation Made Real: Art and National Identity in Western Europe, 1600-1850. Oxford: Oxford University Press, 2013.

Smith, Anthony D. "Biblical beliefs in the shaping of modern nations". Nations and Nationalism 21, no. 3 (2015): 403-22.

Sommer, Doris. Foundational Fictions: The National Romances of Latin America. Los Angeles \& Oxford: University of California Press, 1991.

Stahl, Dale J. An Analysis of Ernest Gellner's Nations and Nationalism. London: Macat, 2017.

Stearns, Peter N. and Carol Z. Stearns. "Emotionology: Clarifying the History of Emotions and Emotional Standards". The American Historical Review 90, no. 4 (October 1985): $813-36$.

Stengrundet, Elin. "Opprørets variasjoner: Autoritetstematikk i fire dikt av Henrik Wergeland”. PhD diss., Høgskolen i Innlandet, 2018. 
Stynen, Andreas, Maarten van Ginderachter and Xosé M. Núñez Seixas, "Introduction: Emotions and everyday nationalism in modern European history". In Emotions and Everyday Nationalism in Modern European History, edited by Andreas Stynen, Maarten van Ginderachter, and Xosé M. Núñez Seixas, 1-15. New York: Routledge, 2020 .

Tergel, Alf. "Ungkyrkorörelsen och nationalismen”. In Kyrka och nationalism i Norden: Nationalism och skandinavism i de nordiska folkkyrkorna under 1800 -talet, edited by Ingmar Brohed, 343-55. Lund: Lund University Press, 1998.

Thiesse, Anne-Marie. "National Identities: A Transnational Paradigm". In Revisiting Nationalism: Theories and Processes, edited by Alain Dieckhoff and Christophe Jaffrelot, 122-43. New York: Palgrave Macmillan, 2005.

Thiesse, Anne-Marie. La fabrique de l'écrivain national: Entre littérature et politique. Paris: Gallimard, 2019.

Thorkildsen, Dag. “For Norge, kjempers fødeland' - norsk nasjonalisme, skandinavisme og demokrati i det 19. århundre". In Kyrka och nationalism i Norden: Nationalism och skandinavism i de nordiska folkkyrkorna under 180o-talet, edited by Ingmar Brohed, 129-55. Lund: Lund University Press, 1989.

Valenius, Johanna. Undressing the Maid: Gender, Sexuality and the Body in the Construction of the Finnish Nation. Helsinki: The Finnish Literature Society, 2004.

Wrede, Johan. Världen enligt Runeberg: En biografisk och idéhistorisk studie. Helsingfors: Svenska litteratursällskapet i Finland \& Stockholm: Bokförlaget Atlantis, 2005. 